\title{
3 Research Square \\ Surface Runoff Estimation Of Sind River Basin Using SCS-CN Method And GIS Technology
}

\section{Abanish Sharma}

Suresh Gyan Vihar University https://orcid.org/0000-0001-7089-6883

Shruti Kanga ( $\sim$ shruti.kanga@mygyanvihar.com )

Suresh Gyan Vihar University https://orcid.org/0000-0003-0275-5493

\section{Research Article}

Keywords: Rainfall, Runoff, GIS, SCS-CN method, Curve Number River basin

Posted Date: July 14th, 2020

DOI: https://doi.org/10.21203/rs.3.rs-41218/v1

License: (c) (i) This work is licensed under a Creative Commons Attribution 4.0 International License. Read Full License 


\section{Abstract}

Rainfall and runoff are significant hydrologic component in the water resources assessment. Rainfall is the primary source of recharge into the ground water. Understanding of rainfall and runoff is necessary for assessment of water availability. The runoff generation procedure is extremely complex. Accurate runoff assessment is carried out for useful management and improvement of water resources. Many methods are available to estimate runoff from rainfall; however, the SCS-CN method still remains the most popular, fruitful and frequently used method. Runoff curve number $(\mathrm{CN})$ is a key factor of the SCS$\mathrm{CN}$ method and it is depends on land use/land cover (LULC), soil type, and antecedent soil moisture (AMC). Different parameters, like land use/land cover, hydrological soil characteristics (HSG), rainfall data (P), Potential Maximum Retention (S), Antecedent Moisture Condition (AMC), Weighted Curve Number (CN), that are the mandatory inputs to SCS model, have been either derived from remote sensing data or from conventional data collection systems. The advance application of Remote Sensing and GIS techniques used to estimate surface runoff based on different parameters. The total area of present study is $26207.02 \mathrm{~km}^{2}$ of Sind River Basin, located in the northern part of Madhya Pradesh, India. The daily rainfall data of 23 weather stations (2005-2014) was collected and used to predict the daily runoff from the Sind river basin using SCS-CN method and GIS technique for the duration of 2005-2014, annual average of daily rainfall are $777.07 \mathrm{~mm}$ and annual average of daily runoff calculated for Sind river basin are $133.71 \mathrm{~mm}$. The developed rainfall-runoff model has been used to understand the characteristics of the watershed and its runoff.

\section{Introduction}

Water is unique source on the planet that no living can survive without it. Water is used in many sectors of our environment that serve human being directly or indirectly. Among others most crucial scopes of water for human beings is drinking, agriculture, energy production or transportation. All land of earth surface is a part of a watershed or river basin and all is formed by the water which flows over it and all the way through it. Runoff is very significant hydrologic component in the water resources assessment. Rainfall characteristics like intensity, duration and distributions are the main factors for the occurrence and quantity of runoff. Water flow which occurs when soil is infiltrated with high capacity and surplus water from precipitation, snowmelt or other sources of water flows over the land called surface runoff. This is a most important element of the hydrologic cycle. The relationship between quantity of precipitation and the consequential quantity of runoff is generally dependent on soil Infiltration. Rainfallrunoff relationship is extremely complex, influenced by various storm and drainage characteristics. There are number of methods available for finding out the runoff such as rational method, Green-Ampt method, and SCS-CN method (Dhvani Tailor and Narendra J. Shrimali, 2016).

In the present study SCS-CN method and GIS techniques used for surface runoff estimation. The Soil Conservation Service-Curve Number (SCS-CN) method developed by National Resources Conservation 
Service (NRSC), United States Department of Agriculture (USDA) in 1969, is simple, predictable and stable conceptual method for estimation of direct runoff depth based on storm rainfall depth. Numeric catchment characteristics are the foundation of runoff determination in this method. The aim of the process is to find out the precise runoff curve number $(\mathrm{CN})$ that defines the runoff potential. Combination of land use type, soil group and Antecedent Soil Moisture Condition (AMC) used for estimation of runoff curve number. The type of land use, hydrologic situation, agricultural management, soil moisture and distribution of soil type, above all are main components for rainfall runoff analysis. Soil type divided into four Hydrologic Soil Groups (HSG) that is A, B, C and D. Soil type under "A" hydrologic soil group having high infiltration rate, whereas soils having low infiltration rate comes under " $D$ " hydrologic soil group. Remote sensing and GIS techniques are very useful for planning, development and management of natural resources as well as water resources in worldwide research. GIS environment facilitate particular in integrating of various thematic data sets in one platform and perform spatial analysis for decision making.

\section{Study Area}

Sind river basin falls in the northern part of Madhya Pradesh, State of Indian country. Its located between $77^{\circ} 10^{\prime} 19^{\prime \prime}$ to $79^{\circ} 07^{\prime} 32^{\prime \prime}$ E longitudes and $24^{\circ} 01^{\prime} 04^{\prime \prime}$ to $26^{\circ} 47^{\prime} 01^{\prime \prime} \mathrm{N}$ latitude and the total area of proposed study is $26207.02 \mathrm{sq} \mathrm{km}$. River Sind originates in Vidisha district and flow in Guna, Ashok Nagar, Shivpuri, Seopur, Datia, Gwalior, Morena and Bhind district and join river Chambal in Etawah district of Uttar Pradesh near Bhind district of Madhya Pradesh. Major tributaries of Sind River are Mahuar, Parbati, Pahuj, and Kunwari. Sind river basin is characterized by hot summer and dryness climatic region except during southwest monsoon season. Soil types of study area can be grouped as under black cotton soil, sandy soil, sandy loam, clayey loam, fine soil and laterite soil.

\section{Methodology}

\begin{tabular}{|cllll|}
\hline $\begin{array}{l}\text { S. } \\
\text { No }\end{array}$ & Used Data & $\begin{array}{l}\text { Scale/Data } \\
\text { Resolution }\end{array}$ & Year/ Range & Source \\
\hline 1 & Rainfall & $2.5^{\circ} \times 2.5^{\circ}$ & $2005-2014$ & http://www.globalweather.tamu.edu \\
\hline $\begin{array}{c}\text { SOI } \\
\text { Toposheet }\end{array}$ & $1: 50000$ & 1960 & Survey of India, Dehradun. \\
\hline 3 & $\begin{array}{l}\text { LANDSAT- } \\
8\end{array}$ & $30 \mathrm{M}$ & $\begin{array}{c}\text { Sep 2013 \& } \\
\text { Jan, 2014 }\end{array}$ & USGS Earth Explorer \\
\hline 4 & Soil map & $1: 250000$ & 1976 & $\begin{array}{c}\text { National Bureau of Soil Survey and Land } \\
\text { use Planning, Bhopal. }\end{array}$ \\
\hline
\end{tabular}

Table-1: Used data in present study. 
Land use/Land cover ( $L U / L C)$ ): Thisis one of the very important variables for runoff estimation. Land use map prepared by using Landsat-8 satellite imagery using ERDAS Imagine and Arc GIS software's. On screen digitization procedure applied for land use map preparation through visual interpretation of satellite imagery on 1:50000 scale using Arc GIS Software. Various LU/LC classes identified namely agricultural land, built-up area, forest, wastelands and water bodies (Figure-2). The detail statistics of land use/land cover of the study area is shown in Table-4.

Soil: To assess the rainfall water as a surface runoff, Soil texture is very important for hydrologic soil group determination hence needful thematic layer of soil type obtained from National Bureau of Soil Survey \& Land Use Planning (NBSS\&LUP).

Hydrological Soil Group (HSG): HSG maps of study area were prepared using Arc GIS software on the basis of soil texture. HSG is expressed as four groups; Group A, B, C, and D, according to the soil's minimum infiltration rate.

Curve Number (CN): The overlay operation is performed using the land use map and hydrologic soil group map to identify land use and soil group for each polygon and determine area of every land use classes under same soil group. Curve number ( $\mathrm{CN}$ ) of each unique land use-soil groups are assigned within the basin boundary based on standard SCS curve number method (Table 6).

Rainfall: Rainfall data were downloaded from theNational Centers for Environmental Prediction (NCEP), Climate Forecast System Reanalysis (CFSR) dataset (http://globalweather.tamu.edu) in comma separated values (.csv) file format which are authenticated data sources (Sharma et al., 2015). CFSR has published daily/monthly rainfall, minimum, maximum \& mean temperature, wind speed, relative humidity and solar radiation/sun hours on regular latitude, longitude grid of $2.5 \times 2.5$ degree. Daily observed Rainfall data for the period 2005-2014 used for present study which have been recorded by 23 weather stations covering the study area. IDW interpolation technique in Arc GIS software has been used to find out spatial distribution of rainfall in study area.

\section{SCS-CN Model:}

Soil Conservation Service Curve Number (SCS-CN) method is the most commonly used experimental method to calculate the direct runoff from a watershed/river basin (USDA, 1972). The Curve Number (SCS-CN) Equation usually a relationship between runoff volume and rainfall volume. The SCS-CN technique explaining the water balance equation can be articulated as given below (Mishra and Singh 2003).

$$
\mathrm{Q}=\frac{(\mathrm{P}-\mathrm{Ia})^{\wedge} 2}{\mathrm{P}-\mathrm{Ia}+\mathrm{S}}
$$




\section{Where;}

$\mathrm{Q}$ is the runoff depth (to get volume, multiply by the basin area)

$\mathrm{P}$ is the rainfall depth

la is the initial abstraction

$S$ is the basin storage.

All units of depth are in $\mathrm{mm}$.

The amount of rainfall that falls before runoff is initiated can be conceptualized as initial abstraction and this is generally assumed to be $0.2 \mathrm{~S}$.

Eq. is usually written as (Dwivedi P. et al, 2017):

$$
\mathrm{Q}=\frac{(\mathrm{P}-0.2 \mathrm{~S})^{\wedge} 2}{\mathrm{P}+0.8 S}
$$

For the Indian condition the $\mathrm{CN}$ is related to $\mathrm{S}$ with

$$
\mathrm{S}=\frac{1000-10}{\mathrm{CN}} \text { or } S=\frac{25400-254}{\mathrm{CN}}
$$

The $\mathrm{CN}$ (dimensionless number ranging from 0 to 100) is determined from a table, based on land use/land cover (LU/LC), hydrological soil group (HSG) and Antecedent moisture conditions (AMC). Hydrologic Soil Group (HSG) is generally divided into four groups (A, B, C and D) with respect to the rate of the soil's infiltration in the watershed area. Antecedent Moisture Condition (AMC) is expressed in three levels (AMC I, AMC II and AMC III), according to precipitation limits for dormant and growing seasons. CN value was adopted from Technical release (USDA, TR-55, 1986). Although, SCS technique is formerly designed for use in watersheds of $15 \mathrm{~km}^{2}$, and it has been modified for application to larger watersheds/basin by weighing curve numbers with respect to watershed/basin area.

Equation of Weighted Curve Number $(\mathrm{CNw})$ given below;

$$
\mathrm{CNw}=\frac{\sum(\mathrm{CNi} * \mathrm{Ai})}{\mathrm{A}}
$$

Where; 
$\mathrm{CNw}=$ Weighted curve number

$\mathrm{CNi}=$ Curve number

$\mathrm{Ai}=$ Area with curve number $\mathrm{CNi}$

\section{Antecedent Moisture Condition (AMC)}

AMC refers to the wetness that is present in the soil at the start of the rainfall runoff incident under consideration. It is well recognized that initial abstraction and infiltration are governed by AMC. Three level of AMC are recognized by SCS as given below:

Table 2: Classification of Antecedent Moisture Conditions (AMC)

\begin{tabular}{|c|c|c|c|}
\hline \multirow[t]{3}{*}{$\begin{array}{l}\text { AMC } \\
\text { Class }\end{array}$} & \multirow[t]{3}{*}{ Soil Characteristics } & \multicolumn{2}{|c|}{$\begin{array}{l}\text { Total } 5 \text { day } \\
\text { Antecedent } \\
\text { rainfall(mm) }\end{array}$} \\
\hline & & Dormant & Growing \\
\hline & & Season & Season \\
\hline $\begin{array}{l}\text { AMC- } \\
\text { I }\end{array}$ & Soils are dry not to wilting point, Cultivation has taken place & $<13 \mathrm{~mm}$ & $\begin{array}{l}<36 \\
\mathrm{~mm}\end{array}$ \\
\hline $\begin{array}{l}\text { AMC- } \\
\|\end{array}$ & Average Condition & $\begin{array}{l}13- \\
28 \mathrm{~mm}\end{array}$ & $\begin{array}{l}36-53 \\
\mathrm{~mm}\end{array}$ \\
\hline $\begin{array}{l}\text { AMC- } \\
\text { III }\end{array}$ & $\begin{array}{l}\text { Heavy or light Rainfall and low temperatures have occurred within } \\
\text { the last } 5 \text { days; saturated soils }\end{array}$ & $>28 \mathrm{~mm}$ & $>53 \mathrm{~mm}$ \\
\hline
\end{tabular}

(Source: Handbook of Hydrology, 1972).

The deviation of $\mathrm{CN}$ value under AMC II called CNII for diverse land circumstances are usually found in practice. The alteration of CNII to other two AMC conditions can be complete by the following correlation equations,

For AMC-I

$$
\mathrm{CNI}=\frac{4.2 \times \mathrm{CNII}}{10-0.058 \times \mathrm{CNII}}
$$

For AMC-III 


\section{$\mathrm{CNI}=\frac{23 \times \mathrm{CNII}}{10+0.13 \times \mathrm{CNII}}$}

Table 3: USDA-SCS Soil classification.

\begin{tabular}{|c|c|c|c|c|}
\hline $\begin{array}{l}\text { Hydrologic } \\
\text { Soil Group }\end{array}$ & Type of Soil & $\begin{array}{l}\text { Runoff } \\
\text { potential }\end{array}$ & $\begin{array}{l}\text { Infiltration } \\
\text { Rate } \\
\mathrm{mm} / \mathrm{hr}\end{array}$ & Remarks \\
\hline Group A & Deep, well drained sands and gravels & Low & $>7.5$ & $\begin{array}{l}\text { High rate of } \\
\text { water } \\
\text { transmission }\end{array}$ \\
\hline Group B & $\begin{array}{l}\text { Moderately deep, well drained with } \\
\text { moderately fine to coarse textures }\end{array}$ & Moderate & $3.8-7.5$ & $\begin{array}{l}\text { Moderate } \\
\text { rate } \\
\text { of water } \\
\text { transmission }\end{array}$ \\
\hline Group C & $\begin{array}{l}\text { Clay loams, shallow sandy loam, soils } \\
\text { with moderately fine to fine textures }\end{array}$ & Moderate & $1.3-3.8$ & $\begin{array}{l}\text { Moderate } \\
\text { rate } \\
\text { of water } \\
\text { transmission }\end{array}$ \\
\hline Group D & $\begin{array}{l}\text { Clay soils that swell significantly when } \\
\text { wet, heavy plastic and soils with a } \\
\text { permanent high water table }\end{array}$ & High & $<1.3$ & $\begin{array}{l}\text { Moderate } \\
\text { rate } \\
\text { of water } \\
\text { transmission }\end{array}$ \\
\hline
\end{tabular}

\section{Result And Discussion}

In the present study, SCS-CN method used for surface runoff estimation. The runoff generation method is extremely complex, nonlinear, dynamic in character, and affected by numerous interconnected physical factors. Precise runoff assessment is carried out for valuable management and development of water resources. In Sind river basin drought like situation prevails every year due to low average annual rainfall and high runoff.

Land use: The basin constitutes different land use/ land cover classes and present research reveals that agriculture is dominant land use class in the study region. LU/LC map shown that nearly $12847.28 \mathrm{~km}^{2}$ $(49.02 \%)$ of the sind river basin area has been used for agricultural purposes, the area of Forest is 
$6006.21 \mathrm{~km}^{2}(22.92 \%)$, Wasteland area nearly $6523.18 \mathrm{~km}^{2}(24.89 \%)$, Built up area is about $447.86 \mathrm{~km}^{2}$ (01.71\%) and River/Water bodies observed $382.49 \mathrm{~km}^{2}(01.46 \%)$ in study area.

\begin{tabular}{|c|c|c|c|c|}
\hline S. No. & LU/LC Class & & Area in $\mathrm{km}^{2}$ & Area in \% \\
\hline 1. & Built Up Area & Built-up & 447.86 & 01.71 \\
\hline 2. & \multirow[t]{4}{*}{ Agriculture Land } & Rabi Crop & 4596.56 & 17.54 \\
\hline 3. & & Kharif Crop & 2091.00 & 07.98 \\
\hline 4. & & Double Crop (Kharif+Rabi) & 3758.73 & 14.34 \\
\hline 5. & & Fellow Land & 2400.99 & 09.16 \\
\hline 6. & \multirow[t]{3}{*}{ Forest } & Dense Forest & 1125.61 & 04.30 \\
\hline 7. & & Open Forest & 2185.36 & 08.34 \\
\hline 8. & & Scrub Forest & 2695.23 & 10.28 \\
\hline 9. & \multirow[t]{4}{*}{ Wasteland } & Land With Scrub & 2883.92 & 11.00 \\
\hline 10. & & Land Without Scrub & 1452.24 & 05.54 \\
\hline 11. & & Barren Rockey/Stony & 07.01 & 00.03 \\
\hline 12. & & Gullied/Ravenous & 2180.02 & 08.32 \\
\hline 13. & \multirow[t]{3}{*}{ River \& Water Bodies } & Lakes/Ponds & 34.68 & 00.13 \\
\hline 14. & & Dam/Reservoirs & 132.96 & 00.51 \\
\hline 15. & & River & 214.85 & 00.82 \\
\hline Total & & & 26207.02 & 100 \\
\hline
\end{tabular}

Table 4: Land use/Land cover classification Statistics.

Hydrologic Soil Group: Based on the hydrological soil group, the maximum area of Sind river basin is characterized under group $C$ of hydrological soil that is nearly $17046.04 \mathrm{~km}^{2}(65.05 \%)$, then group $B$ hydrological soil is $7099.08 \mathrm{~km}^{2}(27.09 \%)$, group A hydrological soil observed as $1278.32 \mathrm{~km}^{2}(04.88 \%)$, group D hydrological soil observed as $400.19 \mathrm{~km}^{2}(01.53 \%)$ and nearly $382.49 \mathrm{~km}^{2}(01.46 \%)$ area found as unclassified or river/water bodies in the study area. 


\begin{tabular}{|llll|}
\hline S. No. & Hydrological Soil Group & Area in $\mathbf{k m 2}$ & Area in \% \\
\hline 1. & Group A & 1278.32 & 04.88 \\
\hline 2. & Group B & 7099.08 & 27.09 \\
\hline 3. & Group C & 17046.04 & 65.05 \\
\hline 4. & Group D & 400.19 & 01.53 \\
\hline 5. & River \& Water Bodies & 382.49 & 01.46 \\
\hline Total Study Area & $\mathbf{2 6 2 0 7 . 0 2}$ & $\mathbf{1 0 0}$ \\
\hline
\end{tabular}

Table 5: Hydrological Soil Group classification Statistics.

\section{Area Weighted Curve Number}

Overlay analysis (Union) performed with soil and land use map and hydrological soil group map prepared new PAT (polygon attribute table) using Arc GIS 9.3. The result obtained from this HSG-PAT used to compute the total area weighted curve number of the study area. 


\begin{tabular}{|c|c|c|c|c|c|c|c|}
\hline $\begin{array}{l}\text { S. } \\
\text { No. }\end{array}$ & $\begin{array}{l}\text { Soil } \\
\text { Type } \\
\text { (HSG) }\end{array}$ & Land use & $\begin{array}{l}\text { Area in } \\
\text { Sq Km }\end{array}$ & CN & $\begin{array}{l}\text { Area in } \\
\text { Hectare }\end{array}$ & $C N * A$ & WCN \\
\hline 1 & Group A & \multirow[t]{4}{*}{ Builtup } & 21.71 & 57 & 2170.9508 & 123744.1956 & \multirow{4}{*}{$\begin{array}{l}\text { AMC } \\
\text { I } \\
63.07\end{array}$} \\
\hline 2 & Group B & & 89.59 & 72 & 8959.0886 & 645054.3792 & \\
\hline 3 & Group C & & 328.96 & 81 & 32895.9199 & 2664569.512 & \\
\hline 4 & Group D & & 7.32 & 86 & 731.7788 & 62932.9768 & \\
\hline 9 & Group A & \multirow[t]{4}{*}{ Dam/Reservoirs } & 7.13 & 98 & 713 & 69874 & \multirow{3}{*}{$\begin{array}{l}\text { AMC } \\
\text { II } \\
79.58\end{array}$} \\
\hline 10 & Group B & & 33.21 & 98 & 3321 & 325458 & \\
\hline 11 & Group C & & 76.18 & 98 & 7618 & 746564 & \\
\hline 12 & Group D & & 16.43 & 98 & 1643 & 161014 & $\begin{array}{l}\text { AMC } \\
\text { III }\end{array}$ \\
\hline 13 & Group A & \multirow[t]{4}{*}{ Dense Forest } & 34.94 & 25 & 3493.8802 & 87347.005 & \multirow[t]{19}{*}{90.12} \\
\hline 14 & Group B & & 977.20 & 55 & 97719.8264 & 5374590.452 & \\
\hline 15 & Group C & & 104.51 & 72 & 10451.3071 & 752494.1112 & \\
\hline 16 & Group D & & 9.19 & 77 & 918.995 & 70762.615 & \\
\hline 17 & Group A & \multirow{4}{*}{$\begin{array}{l}\text { Double Crop } \\
\text { (Kharif+Rabi) }\end{array}$} & 102.14 & 65 & 10214.0257 & 663911.6705 & \\
\hline 18 & Group B & & 140.08 & 76 & 14008.061 & 1064612.636 & \\
\hline 19 & Group C & & 2311.42 & 84 & 231141.7739 & 19415909.01 & \\
\hline 20 & Group D & & 39.30 & 88 & 3930.3636 & 345871.9968 & \\
\hline 21 & Group A & \multirow[t]{4}{*}{ Fellow Land } & 186.71 & 77 & 18671.2936 & 1437689.607 & \\
\hline 22 & Group B & & 209.61 & 86 & 20961.4798 & 1802687.263 & \\
\hline 23 & Group C & & 3093.75 & 91 & 309375.3383 & 28153155.79 & \\
\hline 24 & Group D & & 77.76 & 94 & 7776.0982 & 730953.2308 & \\
\hline 25 & Group A & \multirow[t]{4}{*}{ Kharif Crop } & 127.56 & 65 & 12756.3974 & 829165.831 & \\
\hline 26 & Group B & & 367.71 & 76 & 36771.4297 & 2794628.657 & \\
\hline 27 & Group C & & 1560.62 & 84 & 156062.3481 & 13109237.24 & \\
\hline 28 & Group D & & 35.09 & 88 & 3508.8128 & 308775.5264 & \\
\hline 29 & Group A & \multirow[t]{3}{*}{ Lakes/Ponds } & 6.73 & 98 & 673 & 65954 & \\
\hline 30 & Group B & & 13.32 & 98 & 1332 & 130536 & \\
\hline 31 & Group C & & 9.41 & 98 & 941 & 92218 & \\
\hline
\end{tabular}




\begin{tabular}{|c|c|c|c|c|c|c|}
\hline 32 & Group D & & 5.21 & 98 & 521 & 51058 \\
\hline 33 & Group A & \multirow[t]{4}{*}{ Land With Scrub } & 179.49 & 45 & 17948.9329 & 807701.9805 \\
\hline 34 & Group B & & 313.46 & 66 & 31346.3101 & 2068856.467 \\
\hline 35 & Group C & & 2332.34 & 77 & 233233.5771 & 17958985.44 \\
\hline 36 & Group D & & 67.90 & 83 & 6790.1363 & 563581.3129 \\
\hline 37 & Group A & \multirow[t]{4}{*}{ Land Without Scrub } & 64.36 & 77 & 6435.5844 & 495539.9988 \\
\hline 38 & Group B & & 784.60 & 86 & 78460.4213 & 6747596.232 \\
\hline 39 & Group C & & 559.98 & 91 & 55997.7427 & 5095794.586 \\
\hline 40 & Group D & & 45.39 & 94 & 4538.8516 & 426652.0504 \\
\hline 41 & Group A & \multirow[t]{4}{*}{ Open Forest } & 89.35 & 36 & 8934.8492 & 321654.5712 \\
\hline 42 & Group B & & 1786.54 & 61 & 178654.1986 & 10897906.11 \\
\hline 43 & Group C & & 298.54 & 73 & 29854.1982 & 2179356.469 \\
\hline 44 & Group D & & 11.29 & 79 & 1129.3765 & 89220.7435 \\
\hline 45 & Group A & \multirow[t]{4}{*}{ Rabi Crop } & 174.94 & 65 & 17493.9803 & 1137108.72 \\
\hline 46 & Group B & & 198.86 & 76 & 19886.3702 & 1511364.135 \\
\hline 47 & Group C & & 4164.46 & 84 & 416446.478 & 34981504.15 \\
\hline 48 & Group D & & 60.06 & 88 & 6005.8523 & 528515.0024 \\
\hline 49 & Group A & \multirow[t]{4}{*}{ River } & 33.53 & 98 & 3353 & 328594 \\
\hline 50 & Group B & & 47.45 & 98 & 4745 & 465010 \\
\hline 51 & Group C & & 116.64 & 98 & 11664 & 1143072 \\
\hline 52 & Group D & & 17.24 & 98 & 1724 & 168952 \\
\hline 53 & Group A & \multirow[t]{4}{*}{ Scrub Forest } & 198.77 & 45 & 19876.7793 & 894455.0685 \\
\hline 54 & Group B & & 2203.69 & 71 & 220369.3317 & 15646222.55 \\
\hline 55 & Group C & & 274.37 & 81 & 27437.4418 & 2222432.786 \\
\hline 56 & Group D & & 18.66 & 89 & 1866.072 & 166080.408 \\
\hline 57 & Group A & \multirow{4}{*}{$\begin{array}{l}\text { Wasteland (Barren } \\
\text { Rockey/Stony) }\end{array}$} & 0.41 & 65 & 40.9908 & 2664.402 \\
\hline 58 & Group B & & 3.40 & 72 & 339.9811 & 24478.6392 \\
\hline 59 & Group C & & 3.02 & 83 & 301.6243 & 25034.8169 \\
\hline 60 & Group D & & 0.26 & 88 & 25.7033 & 2261.8904 \\
\hline
\end{tabular}




\begin{tabular}{|lllllll|}
61 & Group A & Wasteland (Gullied/ & 97.92 & 77 & 9792.3542 & 754011.2734 \\
\cline { 5 - 6 } 62 & Group B & Ravenous) & 24.22 & 86 & 2422.1496 & 208304.8656 \\
\cline { 5 - 6 } 63 & Group C & 2015.09 & 91 & 201509 & 18337319 \\
\hline 64 & Group D & 27.97 & 94 & 2796.6183 & 262882.1202 \\
\hline Total & & $\mathbf{2 6 2 0 7 . 0 2}$ & $\mathbf{2 6 2 0 7 0 2 . 0 7}$ & $\mathbf{2 0 8 5 4 3 8 8 3 . 5}$ \\
\hline
\end{tabular}

Table 6: Weighted Curve Number for Sind river basin.

\section{Rainfall}

The average annual rainfall is not consistent in this region. Rainfall data from the year of 2005 to 2014 has been used in present study. The average annual rainfall from the year of 2005-2014 observed as $777.07 \mathrm{~mm} /$ year where as high average annual rainfall observed as $995.16 \mathrm{~mm}$ in the year of 2011 and the lowest average annual rainfall observed as $606.69 \mathrm{~mm}$ in the year of 2006.

\section{Runoff Calculation}

Available daily rain fall data from the year 2005 to 2014 has been evaluated in this study. Below Table shows the annual rainfall and runoff for Sind river basin for the period of 2005 to 2014. SCS Curve number method used in this study for runoff estimation. The average annual runoff from the year of 2005-2014 observed as $133.71 \mathrm{~mm} /$ year whereas, the maximum runoff for the river basin estimated $231.43 \mathrm{~mm}$ in the year 2009 and minimum runoff of $32.41 \mathrm{~mm}$ in the year 2006 which is shown in Table 7. 


\begin{tabular}{|llll|}
\hline S. No. & Year & Rainfall $(\mathrm{mm})$ & Runoff $(\mathrm{mm})$ \\
\hline 1. & 2005 & 704.61 & 119.46 \\
\hline 2. & 2006 & 606.69 & 32.41 \\
\hline 3. & 2007 & 629.41 & 88.39 \\
\hline 4. & 2008 & 897.06 & 148.36 \\
\hline 5. & 2009 & 927.24 & 231.43 \\
\hline 6. & 2010 & 859.17 & 117.81 \\
\hline 7. & 2011 & 995.16 & 219.86 \\
\hline 8. & 2012 & 763.12 & 157.29 \\
\hline 9. & 2013 & 705.74 & 80.50 \\
\hline 10. & 2014 & 682.50 & 141.61 \\
\hline Total & & 7770.71 & 1337.12 \\
\hline
\end{tabular}

Table 7: Result of Rainfall - Runoff.

\section{Conclusion}

Present study clearly indicate that SCS-CN method integrated with GIS techniques is very useful for estimation of runoff and this method can be used in watershed management effectively. Variation in runoff potential can be observed in obtained result with different land use/land cover and with different soil conditions in the study area. Most of the river basin is indicating high curve number value which is more than 70 , that indicates high runoff in the Sind river basin. The average annual runoff from the year of 2005-2014 observed as $133.71 \mathrm{~mm} /$ year whereas; the maximum runoff for the river basin estimated $231.43 \mathrm{~mm}$ in the year of 2009 and minimum runoff of $32.41 \mathrm{~mm}$ in the year of 2006 . Available daily rain fall data from the year of 2005 to 2014 has been evaluated in this study. The average annual rainfall observed as $777.07 \mathrm{~mm}$ /year whereas; the maximum rainfall is $995.16 \mathrm{~mm}$ in year of 2009 and minimum rainfall is $606.69 \mathrm{~mm}$ in the year of 2006. Land use of the study area classified into five major classes that is built up, agriculture land, forest, wasteland and river/water bodies. Land use map clearly indicate that agriculture is dominant land use class in the sind river basin. The soil of the study area classified into four hydrological soil groups A, B, C and D with minimum infiltration rate. Soil map indicate that most of the study area covered by group $C$ of hydrological soil group.

\section{Declarations}

\section{ACKNOWLEDGEMENTS}


The authors owe their gratefulness to the Chairmen, Chief Mentor and Vice-Chancellor of Suresh Gyan Vihar University, Jaipur for providing institutional facilities to complete this work. Authors also gratefully thanks to the Coordinator and Faculty of Centre for Climate Change and Water Research, Suresh Gyan Vihar University, Jaipur for their support and guidance to complete this work.

\section{CONFLICTS OF INTEREST}

The authors declare no conflict of interest.

\section{References}

1. Bhardwaj A., Kumar A. and Kumar P. (2017), Snowmelt Runoff Modeling using Geospatial Techniques-A Case Study of upper Catchment of Indus River upto Leh, SGVU Journal of Climate Change and Water Research, Vol. 1, Issue 2, pp 28-32.

2. Dwivedi P., Mishra A., Karwariya S., Goyal S. and Thomas T. (2017), SCS-CN Method for Surface Runoff Calculation of Agricultural Watershed Area of Bhojtal, SGVU Journal of Climate Change and Water Research, Vol. 1, Issue 2, pp 9-12.

3. Ishtiyaq A., Verma V. and Verma M. K., (2015), Application of Curve Number Method for Estimation of Runoff Potential in GIS Environment, 2nd International Conference on Geological and Civil Engineering, IPCBEE, IACSIT Press, Singapore, Vol. 80, Issue 4, pp 16-20.

4. Kumar, A., Kanga, S. and Sudhanshu, (2018), Water Balance Assessment Using Geospatial Techniques: A Review, i-Manager's Journal on Future Engineering and Technology, Vol. 14, Issue 1, pp 55-63.

5. Mishra K. and Singh V. P., (2003), Soil Conservation Service Curve Number (SCS-CN) Methodology, Kluwer Academic Publishers, Dordrecht, The Netherlands.

6. Pal1 B. and Samanta S., (2011), Surface runoff Estimation and Mapping Using Remote Sensing and Geographic Information System, International Journal of Advances in Science and Technology, Vol. 3, Issue 3, pp 106-130.

7. Patel J., Singh N.P., Indra P. and Khalid M., (2015), Surface Runoff Estimation Using SCSCN methodA Case Study on Bhadar Watershed, Gujarat, India, Imperial Journal of Interdisciplinary Research, Vol. 3, Issue 5, pp 1213-1218.

8. Sharma S.K., Kansal M.L. and Tyagi A., (2015), Resource assessment and strategic planning for improvement of water supply to Shimla city in India using geospatial techniques, Egypt Journal of Remote Sensing Space Science, Vol. 18, pp 85-97.

9. Satheeshkumar S., Venkateswaran S. and Kannan R., (2017), Rainfall-runoff estimation using SCS$\mathrm{CN}$ and GIS approach in the Pappiredipatti watershed of the Vaniyar sub basin, South India, Model Earth System Environment Journal, Vol. 3, Issue 24, pp 1-8.

10. Tailor D. and Shrimali N. J., (2016), Surface Runoff Estimation By SCS Curve Number Method Using GIS For Rupen-Khan Watershed, Mehsana District, Gujarat, Journal of Indian Water Resource Society, 
Vol. 36, Issue 4, pp 1-5.

11. United State of Department of Agriculture (USDA), Natural Resources Conservation Service, (1972), Handbook of Hydrology, Technical Release (TR) 55, Second Edition June 1986.

12. Zende A. M., Nagarajan R. and Atal K.R., (2014), Analysis of surface runoff from Yerala River Basin using SCS-CN and GIS, International Journal of Geomatics and Geosciences, Vol. 4, Issue 3, pp 508516.

Figures

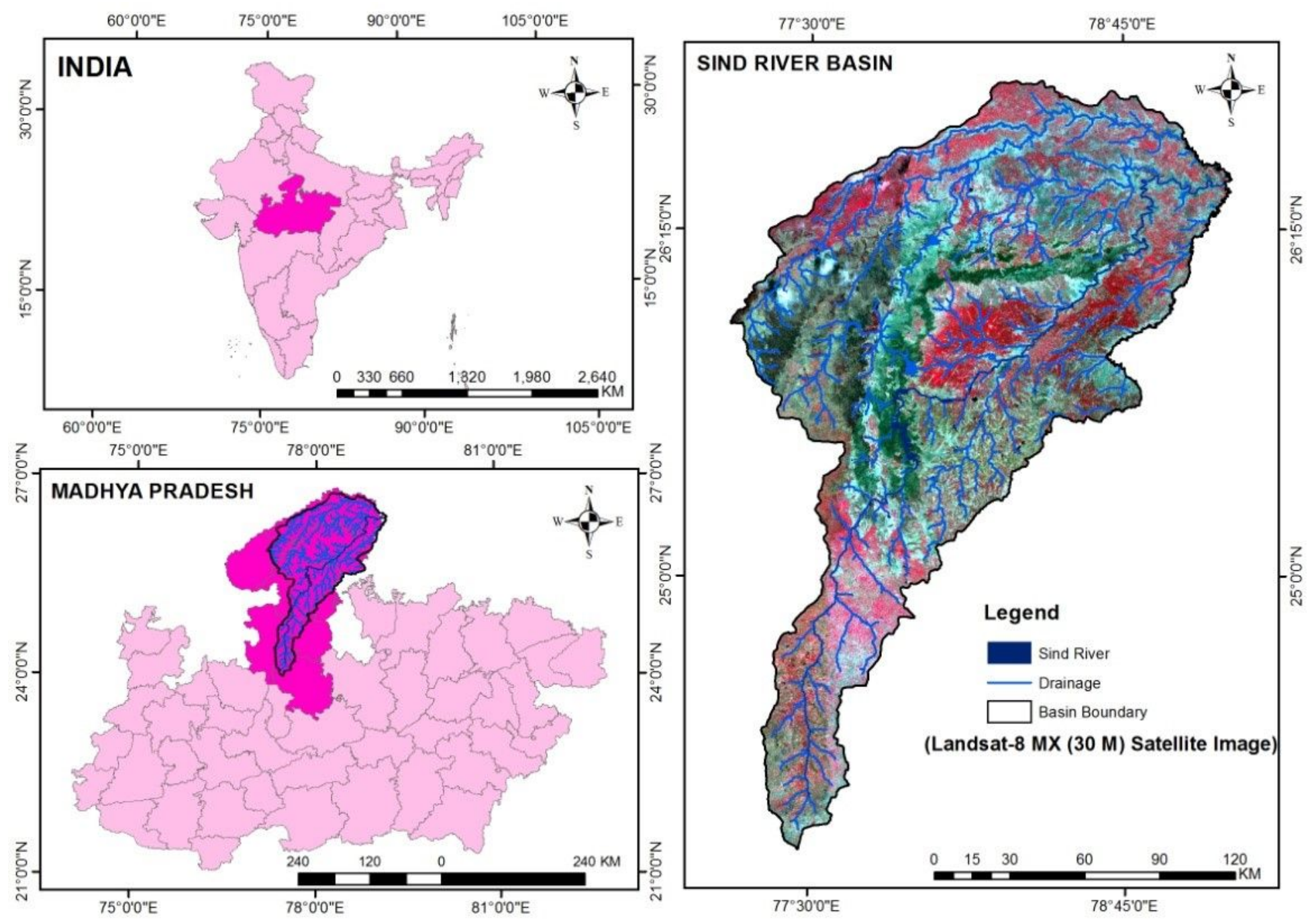

Figure 1

Location map of the study area. 


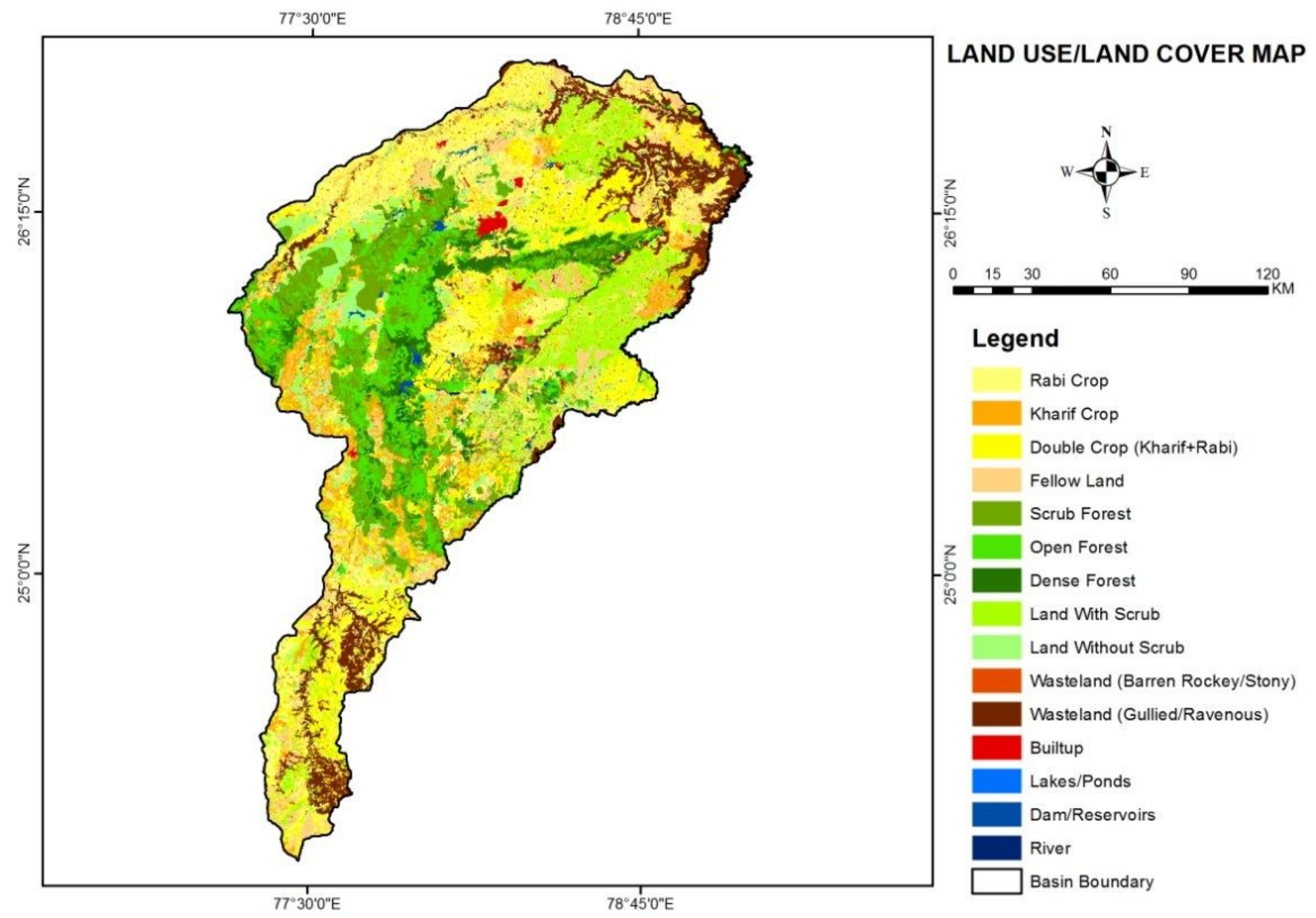

Figure 2

Land use map of the study area. 


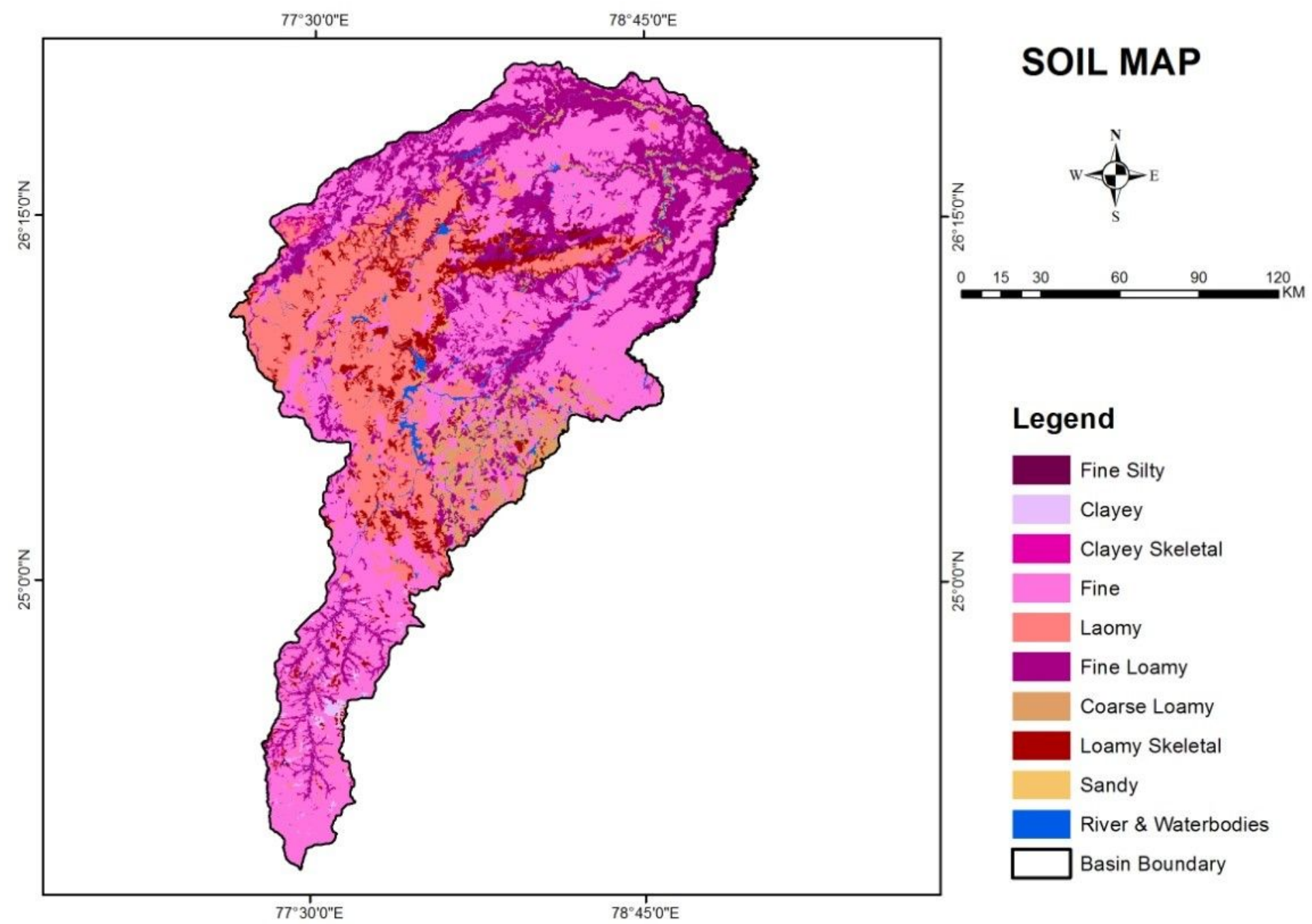

Figure 3

Soil map of the study area. 


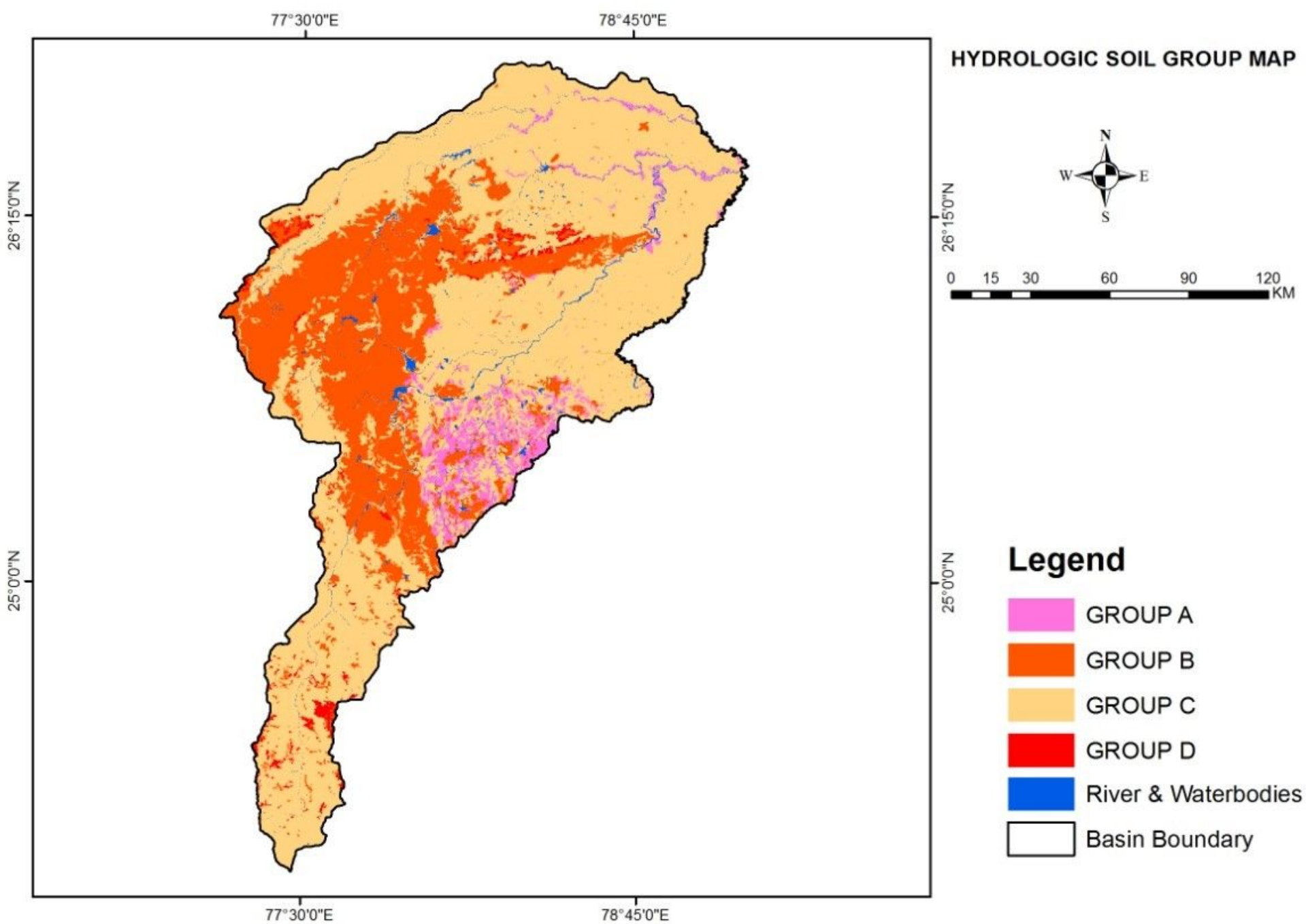

Figure 4

Hydrologic Soil Group map of the study area. 


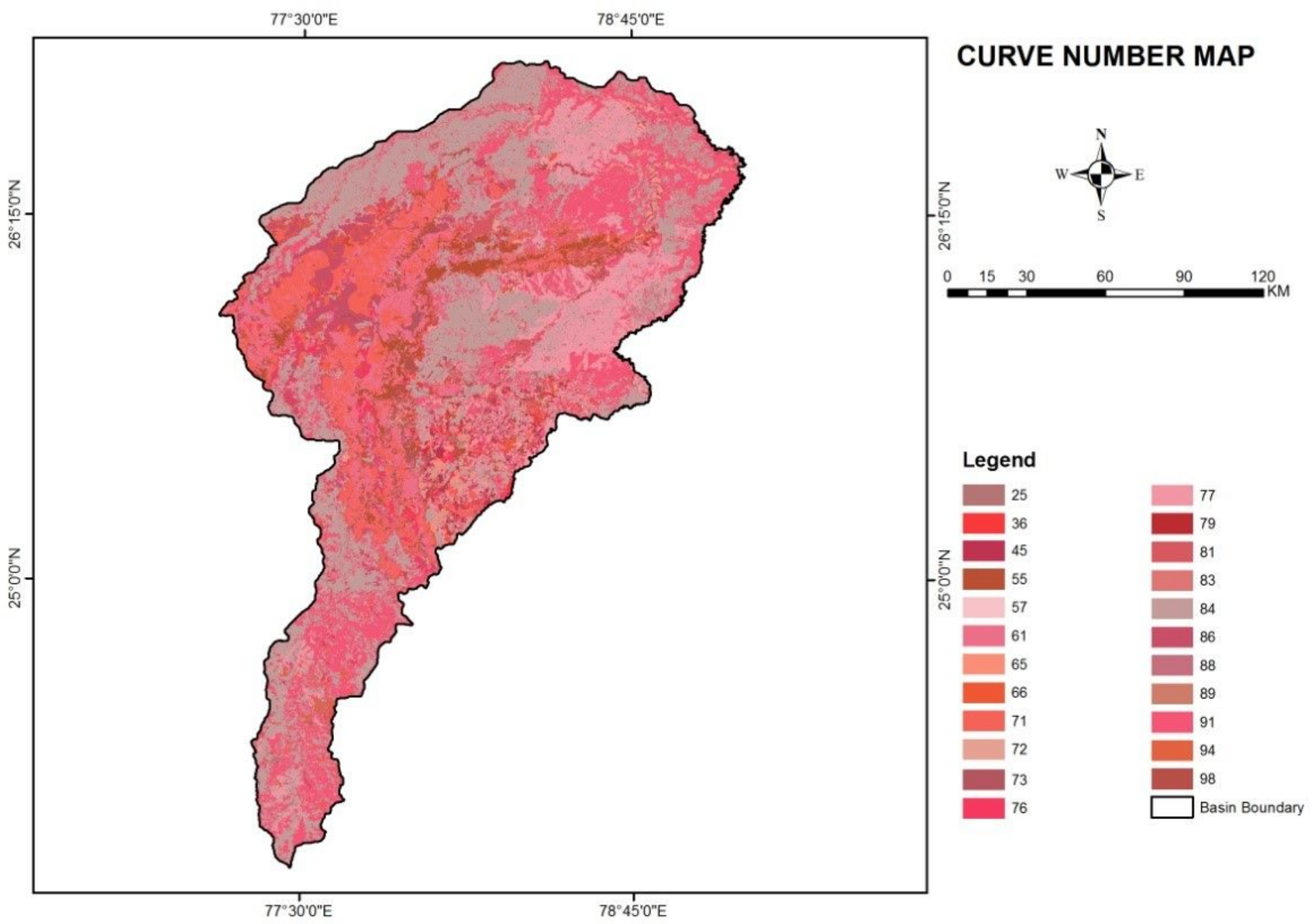

Figure 5

Curve Number map of the study area. 


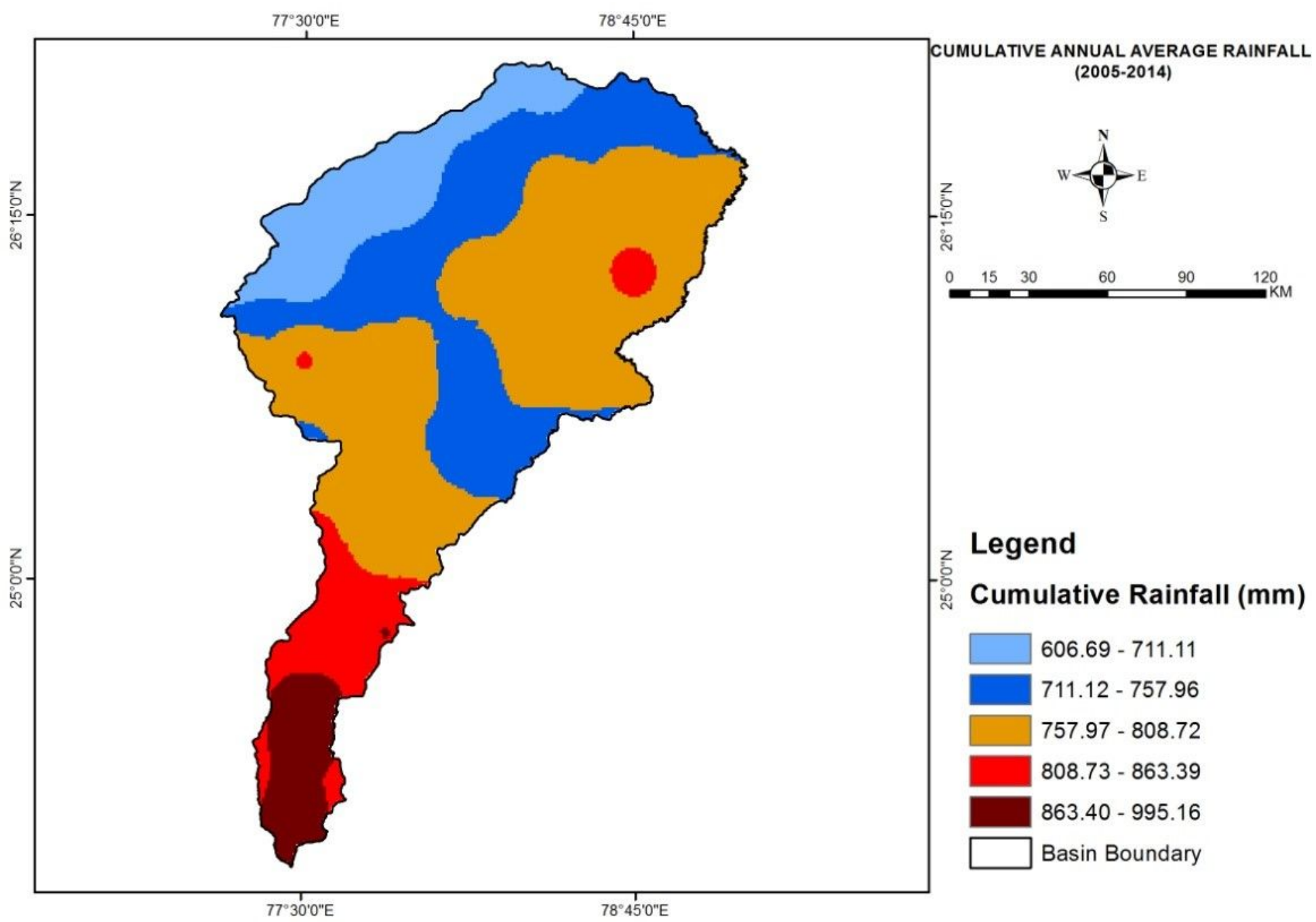

Figure 6

Rainfall distribution map of the study area. 